\title{
Hücre Mikroenkapsülasyonunda Manuel ve Kapsülasyon Sisteminin Hücre İzolasyon Tipi ve Aljinat Yüzdesine Bağlı Verimliliğinin Karşılaştırılması
}

\author{
A Comparison of Cell Micro-encapsulation Efficiency of a Manually \\ Produced and Capsulation System by Depending on the Cell Isolation Type \\ and the Alginate Percentage
}

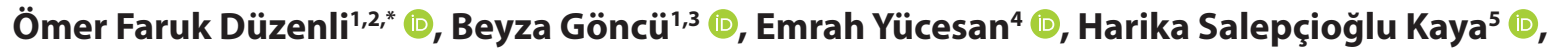 \\ Yeliz Emine Ersoy ${ }^{5}$ (D), Adem Akçakaya ${ }^{5}$ (D)
}

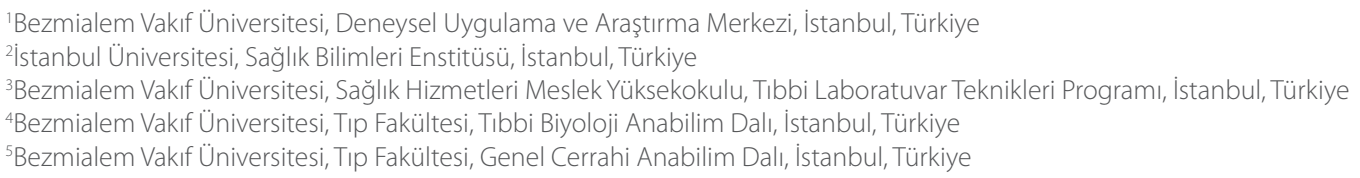

ORCID ID: Ö.F.D. 0000-0002-2938-711X; B.G. 0000-0001-6026-8218; E.Y. 0000-0003-4512-8764; H.S.K. 0000-0001-8557-8140; Y.E.E. 0000-0002-5028-6436; A.A. 0000-0003-3116-7033

Cite this article as: Düzenli ÖF, Göncü B, Yücesan E, Salepçioğlu Kaya H, Ersoy YE, Akçakaya A. Hücre mikroenkapsülasyonunda manuel ve kapsülasyon sisteminin hücre izolasyon tipi ve aljinat yüzdesine bağlı verimliliğinin karşısştıııması. Experimed 2021; 11(3): 162-9.

\section{öz}

Amaç: Birçok endüstriyel sektörde kullanılan polimer malzemeler sağlık bilimlerinde de farklı işlemlerde kullanılmaktadır. Bu işlemlerden biri olan enkapsülasyon sistemi hücre nakli gibi terapötik uygulamalarda tercih edilmektedir. Enkapsülasyon çalışmalarında uygulanacak yaklaşıma göre kapsül yapısında kullanılacak polimer malzeme ve oluşan kapsül boyutu değişmektedir. Aljinat, kahverengi alglerden elde edilen, içeriğindeki farklı polimerik blok oranlarına bağlı olarak değişiklik gösteren doğal polimerlerden biridir. Bu çalışmada, kapsülasyon aşaması için kullanılacak olan değişik aljinat yüzdeleri uygulanarak paratiroid hücrelerinde ideal mikroenkapsülasyon prosedürlerinin belirlenmesi amaçlanmaktadır.

Gereç ve Yöntem: Çalışmada sekonder hiperparatiroidi hastasından alınan bir adet paratiroid hiperplazi dokusundan mekanik ve enzimatik izolasyon yöntemleriyle hücre eldesi gerçekleştirilmiştir. Iki farklı aljinat yüzdesi kullanarak hem manuel olarak hem de kapsülasyon cihazında otomatize olarak iki farklı akış hızı değerlendirilmiştir. Mikroenkapsüle edilen hücreler 64-79 gün boyunca in vitro olarak parathormon miktarları ölçülerek takip edilmiştir.

Bulgular: Değerlendirilen aljinat yüzdelerinden \%2'lik konsantrasyona sahip mikroenkapsüllerin oluşturulmasında kapsülasyon cihazında kullanılan $2 \mathrm{~mL} / \mathrm{dk}$ akış hızıyla morfolojik stabilite göz-

\begin{abstract}
Objective: Many industrial sectors in the health sciences are using polymeric materials for different processes. One of these processes is the encapsulation system mainly preferred in therapeutic applications including cell transplantation. Depending on the main approach, the polymer type and sphere properties differ by the encapsulation method. Alginate is one of the natural polymers that show structural changes depending on different polymer ratios. In this study, our aim is to determine the ideal micro-encapsulation procedures by evaluating different alginate concentrations for the capsulation process of parathyroid cells.
\end{abstract}

Material and Method: In this study, cell isolation of single parathyroid hyperplasia tissue from a patient with secondary hyperparathyroidism was performed by using two methods including mechanical and enzymatic isolation. Two different alginate percentages were used for micro-encapsulation which created manually, and a capsulation system made with two different flow rates. Parathormone levels of micro-encapsulated cells were followed for 64-79 days in vitro.

Results: Morphological stability was observed for $2 \%$ alginate concentration with a flow rate of $2 \mathrm{~mL} / \mathrm{min}$ used group from the micro-encapsulation system. However, parathyroid hormone re- 
lenmiştir. Ayrıca parathormon salınımı açııından hücre izolasyon tipi ve aljinat yüzdeleri arasında benzer sonuçlar elde edilmiştir.

Sonuç: Uzun süreli mikroenkapsülasyon verimliliğinin arttırılması için yapısal ve fonksiyonel açıdan birçok parametrenin belirlenmesi gerekmektedir. Bu çalışma ile enzimatik izolasyon metoduyla elde edilen paratiroid hücrelerinin kapsülasyon sistemi kullanılarak artan akış hızında daha stabil bir yapı oluşturdukları belirlenmiştir.

Anahtar Kelimeler: Paratiroid, mikroenkapsülasyon, ultra saf aljinat, kapsülasyon sistemi, hücre izolasyonu.

\section{GíRiş}

Polimer malzemeler günümüzde birçok endüstriyel sektörde yapıştırıcı olarak ayrıca paketleme, boyama ve kaplama gibi farklı amaçlarla da kullanılmaktadır (1). Bu kullanım alanlarının yanı sıra, polimer malzemeler farmasötik, gıda, kozmetik ve sağlık bilimleri alanlarında enkapsülasyon gibi biyomühendislik uygulamalarında kullanılmaktadır (2). Enkapsülasyon işlemi için kullanılacak olan polimer malzemeler doğal polimerler ve sentetik polimerler olarak iki grupta incelenmektedir. Sentetik polimerlere polietilen glikol, polivinil alkol, poliüretan, polietersülfon, polipropilen, sodyum aljinat gibi birçok örnek verilebilir. Doğal polimerlerin yapımında kullanılan doğal kaynaklara selüloz, kolajen, kitosan ve aljinat gibi malzemeler örnek olarak gösterilebilir (3). Polimer malzemeler kullanılarak gerçekleştirilen enkapsülasyonun ana hedefleri enkapsüle edilen biyolojik maddenin dış çevreden korunmasını sağlamak ve mekanik destek ile yapısal stabilite yaratmaktır (4).

Biyouyumluluk, kullanılacak olan malzemenin biyolojik objelere ve biyolojik objenin kullanılan malzemeye karşı oluşturacağı tolerans olarak tanımlanmaktadır (5). Hücresel terapi veya ilaç taşınımı gibi çalışmalarda kullanılacak enkapsüle edilmiş terapötik ajanların işlevini yerine getirebilmesi ve tedavinin uzun süreli olabilmesi için kapsülasyon aşamasında kullanılan polimer malzemenin biyouyumluluk özelliği önem kazanmaktadır. Biyouyumluluğu ile ön plana çıkmış olan ve FDA tarafından da onaylı aljinat polimeri, enkapsülasyon çalışmalarında en sık kullanılan biyomateryaldir (3).

Aljinat, kahverengi alglerden elde edilen anyonik bir polisakkarittir. Yapısında $\beta$-D-mannuronik (M) ve a-L-guluronik (G) asit blokları içermektedir (6). Yapısında fazla miktarlarda guluronik asit blokları içeren ve aljinatın daha saf hali olan ultra saf aljinat, yapısal olarak daha sert, stabil ve biyouyumluluğu daha yüksek olmaktadır (2). Ultra saf aljinat bu özellikleri sayesinde tip I diyabet $(7,8)$, deneysel olarak tiroit dokusunun kapsüle edilmesi (9), kalıcı hipoparatiroidi tedavisi için paratiroid hücrelerinin kapsülasyonu $(10,11)$ gibi birçok enkapsülasyon temelli çalışmalarda tercih edilmiştir.

Kalıc hipoparatiroidi $(\mathrm{KH})$, iatrojenik nedenlerden dolayı paratiroid dokularının kanlanmasının bozulması yahut paratiroidin tamamen alınması nedeniyle ortaya çıkan bir hastalıktır. Türkiye'de kalıcı hipoparatiroidi hastalığının görülme sıklığı, endemik guatr ülkesi olması nedeniyle daha fazladır (12). $\mathrm{KH}$ hastalığının neticesinde, hipokalsemi, hiperfosfatemi ve düşük parathormon (PTH) seviyesi gibi ciddi klinik semptomlar geliş- lease showed similar results between cell isolation type and alginate percentages.

Conclusion: Increasing the long-term micro-encapsulation efficiency, certain criteria should be determined from structural and functional aspects. In this study, the micro-encapsulation of parathyroid cells obtained by the enzymatic isolation method formed a more stable structure at increasing flow rate by using the capsulation system.

Keywords: Parathyroid, micro-encapsulation, ultra-pure alginate, capsulation system, cell isolation

mektedir (13). Hastaların semptomatik tedavi olarak hayatları boyunca ilaç kullanması gerekmektedir. İlaç tedavisi kesin çözüm olmamakla birlikte birçok yan etkiyi de içinde barındırmaktadır. KH hastalığı için semptomatik tedavi haricinde paratiroid nakli küratif olarak uygulanabilen tek tedavi seçeneğidir. Tarihsel seyir açısından incelenecek olursa, 1911 yılında ilk paratiroid nakli gerçekleştirilmiştir (14). Bu nakilden sonra birçok farklı gereç ve yöntem kullanılarak nakil işlemleri yapılmıştır. Naklin sağkalım süresini uzatmak amacıyla yapılan ilk kapsüle edilmiş paratiroid hücre nakli 1997 yılında gerçekleştirilmiştir (15). Paratiroid nakli, günümüzde de halen uygulanmakta ve geliştirilmesi için birçok çalışma yapılmaktadır (3).

Bu çalışmada, paratiroid hücrelerinin mikroenkapsülasyon aşamasında kullanılacak olan ideal ultra saf aljinat yüzdesinin belirlenmesi, hücre izolasyon metodunun buna bağlı verimliliği ve manuel ve kapsülasyon cihazı kullanılarak oluşturulan kapsüllerin verimliliğinin karşılaştırılarak değerlendirilmesi amaçlanmıştır.

\section{GEREÇ VE YÖNTEM}

Çalışma, Bezmialem Vakıf Üniversitesi girişimsel olmayan araştırmalar etik kurulu onayı ile Helsinki Deklarasyonu prensiplerine uygun olarak gerçekleştirilmiştir (Kabul numarası: 54022451-050.05.04-522). Çalışma kapsamında kullanılan paratiroid dokusu için hastadan imzalanmış gönüllü onam formu alınarak deneysel süreçler başlatılmıştır.

\section{Hücre İzolasyonu}

Çalışma sürecinde sekonder hiperparatiroidi hastasından alınmış tek bir paratiroid dokusu kullanıldı. Doku eşit olacak şekilde ikiye kesilerek hem mekanik yolla hem de enzimatik yolla hücre izole edildi. Hücre izolasyonlarını gerçekleştirmek için Yucesan ve ark. uyguladığı prosedürler takip edildi $(2,16)$. Muse hücre analiz cihazı (Merck Millipore, Germany) kullanılarak hücrelerin canlılık tayinleri belirlendi.

\section{Mikroenkapsülasyon}

Mikroenkapsülasyon aşamalarında kullanılacak olan ultra saf aljinat maddesi (Pronova UP MVG; Nova Matrix, Oslo, Norway) $\% 1,5$ ve $\% 2$ oranlarında hazırlandı. Her iki oranda hazırlanan aljinat maddesi enzimatik ve mekanik olarak iki farklı izolasyon yöntemiyle elde edilen hücreler ile önceden yapılmış çalışmalarla belirlenen \%28 (hücre/hücre+aljinat) oranında her grupta $10 \times 10^{6}$ hücre olacak şekilde ayrı ayrı karıştırıldı. Çalışma kapsamında mikroenkapsülasyon işlemi manuel bir şekilde ve kapsülasyon cihazı kullanılarak uygulanmıştır. 
İlk olarak, hazırlanan hücre-aljinat karışımı kullanılarak manuel enkapsülasyon işlemi gerçekleştirildi. Bu aşamada, karışım 300 mOsm $\mathrm{CaCl}_{2}$ içeren çözeltiye küt uçlu 15 gauge şırınga ucu kullanılarak el ile yavaşça damlatıldı. Çözelti içerisindeki oluşan kapsüller izotonik su ile yıkanarak ortamdaki fazla kalsiyum uzaklaştırıldı. Kapsüller McCoy's (Gibco, Thermo, MA, USA) hücre kültür medyumu içerisine aktarılarak nemli inkübatörde $37^{\circ} \mathrm{C}^{\prime}$ de ve $\% 5 \mathrm{CO}_{2}$ 'de 64 gün boyunca kültüre edildi.

İkinci olarak, kapsülasyon cihazı (Pump 11 Pico Plus Elite Infusion/Withdrawal Programmable Dual Syringe Pump, Harvard Apparatus $^{\mathrm{TM}}$, Holliston, MA, USA) kullanılarak hücre-aljinat karışımı 300 mOsm $\mathrm{CaCl}_{2}$ içeren çözeltiye $1,5 \mathrm{~mL} / \mathrm{dk}$ ve $2 \mathrm{~mL} / \mathrm{dk}$ hızlarında damlatıldı. Damlatma işlemi küt uçlu 25 gauge şırınga ucu kullanılarak gerçekleştirildi. Kapsüller izotonik su ile yıkanıp McCoy's (Gibco, Thermo, MA, USA) hücre kültür medyumuna alındı. Nemli inkübatörde $37^{\circ} \mathrm{C}^{\prime}$ de ve $\% 5 \mathrm{CO}_{2}$ 'de kültüre edilen kapsüller 79 gün boyunca takip edildi.

\section{PTH Seviyesinin Belirlenmesi}

Çalışma süresince manuel olarak, 1,2 mL/dk ve 1,5 mL/dk cihaz hızlarıyla oluşturulan \%1,5'lik aljinatın kullanıldığı kapsüller 1, $7,15,21,28,35,42,49,57$ ve 64. günlerde; \%2'lik aljinatın kullanıldığı kapsüller ise 1, 7, 15, 21, 28, 35, 42, 50, 57, 64, 72 ve 79 . günlerde süpernatant örnekleri toplandı. Değerlendirilen takip süreci, PTH salınımının sonlandığı noktaya kadar gerçekleştirilmiştir. Toplanan süpernatantlardan PTH miktarları insan PTH ELISA kiti (RayBiotech Inc., Norcoss, GA, USA) kullanılarak belirlendi. Absorbans ölçümleri 450 nm'de Mark Microplate Absorbance Reader (Bio-Rad, USA) cihazı kullanılarak gerçekleştirildi.

\section{İstatistiksel Değerlendirme}

Çalışma kapsamında belirlenen PTH değerleri hem zaman hem aljinat yüzdesi ek olarak aljinat yüzdesi ve uygulanan teknikler açısından karşılaştırılması, çift yönlü ANOVA testi (Tukey's multiple comparisons test ve Sidak's multiple comparisons test) ile gerçekleştirilmiştir. $\mathrm{p}<0,05$ olduğu durum anlamlılık olarak değerlendirilmiştir.

\section{BULGULAR}

Çalışmada sekonder hiperparatiroidi hastasından alınan bir paratiroid hiperplazi dokusu kullanıldı. Mekanik ve enzimatik izolasyon yöntemleriyle hücre izolasyonunu gerçekleştirmek için doku iki eşit parçaya bölündü. Akış sitometrisinde mekanik izolasyon ile elde edilen hücrelerin $\% 95,7$ canlılığa ve $67,6 \times 10^{6}$ hücre sayısına sahip olduğu belirlendi (Şekil 1). Devamında, enzimatik izolasyon ile elde edilen hücreler incelendiğinde \%94,4 canlılığa ve toplam $70,2 \times 10^{6}$ hücre sayısına sahip oldukları tespit edildi.

\section{Morfolojik Görünümleri}

Kapsülasyon, manuel olarak ve kapsülasyon cihazında 1,2 mL/ $\mathrm{dk}$ ve $2 \mathrm{~mL} / \mathrm{dk}$ hızları ile gerçekleştirildi. Ardından, izotonik su çözeltisi ile yıkanan kapsüller kültüre edildi. \%1,5'lik aljinat kullanılan gruplar 64 gün, \%2'lik aljinat kullanılan gruplar 79 gün boyunca kültür ortamında takip edildi. Oluşturulan kapsüller, kültüre edilmeden önce ışık mikroskobu ile gözlemlendi (Şekil

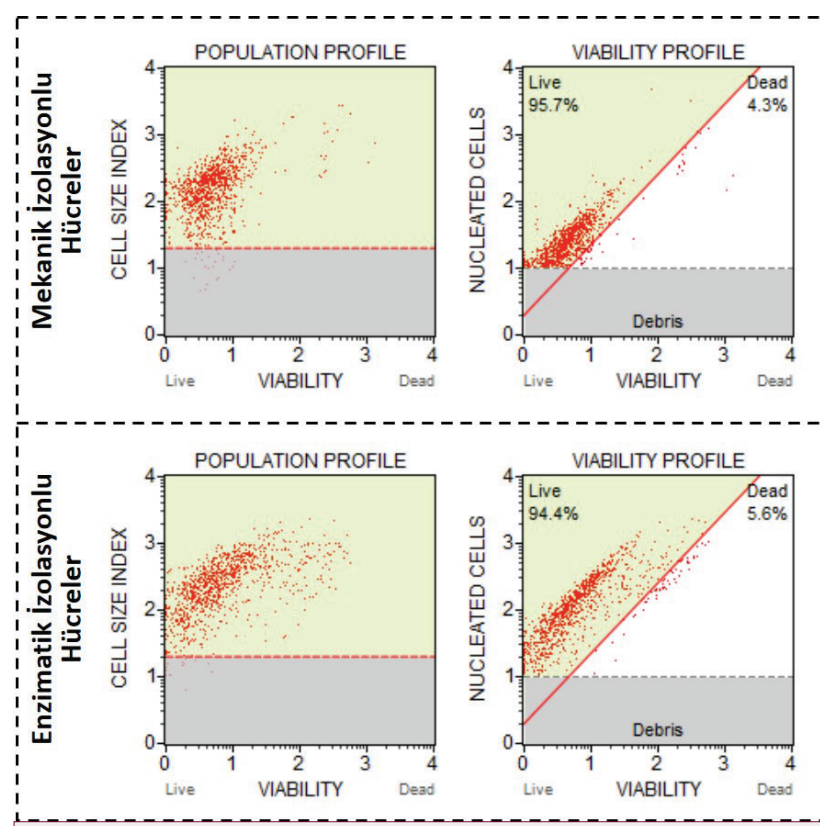

Şekil 1. Paratiroid dokusundan mekanik ve enzimatik olarak iki farklı izolasyon tipi kullanılarak izole edilen hücrelere ait popülasyon ve canlılık profilleri

2). İlk güne ait görüntülerde, $\% 1,5^{\prime}$ lik aljinat gruplarında manuel bir şekilde oluşturulan kapsüllerin çapları $>2 \mathrm{~mm}$ olduğu belirlendi. Aynı durum kapsülasyon cihazında akış hızı 1,2 mL/ dk kullanılarak oluşturulan kapsül örneklerinde izolasyon tipi fark etmeksizin birbirine yakın boyutlarda oluştuğu görüldü. Kapsülasyon cihazında akış hızı 2 mL/dk olan grupta ise kapsül boyutlarının küçüldüğü gözlemlendi. \%2'lik aljinat ile hazırlanan gruplarda da benzer sonuçlar elde edildi. Manuel olarak ve kapsülasyon cihazında akış hızı 1,2 mL/dk olan kapsül örneklerinde kapsüllerin boyutlarının benzer olduğu, akış hızı $2 \mathrm{~mL} / \mathrm{dk}$ olan kapsül boyutlarının hızın artışına bağlı olarak küçüldüğü tespit edildi. \%2'lik aljinat grubundaki enzimatik izolasyonlu örneklerde hücre yoğunluğunun daha az olduğu kapsülün şeffaf bir görünüme sahip olmasından anlaşılmaktadır (Şekil 2).

Takip süreçlerinde; \%1,5 aljinat konsantrasyonu uygulanan enzimatik izolasyonlu hücrelerin kapsüle edildiği grupta kültürün 28. gününden itibaren yüzeysel çatlamalar oluşmuştur. Bu çatlamaların derinlikleri manuel olarak oluşturulan grupta daha fazladır. \%2'lik aljinatın değerlendirildiği grupta ise; mekanik izolasyonlu hücre gruplarında 49. günden sonra çatlayan yüzeysel alanların olduğu gözlenmiş fakat enzimatik izolasyonlu hücre gruplarında herhangi bir yapısal bozulma belirlenmemiştir.

\section{PTH Salınımına \%1,5 Aljinat Konsantrasyonunun Etkisi}

Mikroenkapsüllerin fonksiyonel olup olmadıkları salınan PTH miktarı ile belirlenmiştir. Mekanik izolasyonlu hücrelerin kullanıldığı; ilk grupta manuel yöntemle yapılan kapsüllerin PTH seviyesi 1. ve 7. günde anlamlı şekilde artmıştır $(p=0,0443)$. 15. günden itibaren, 21. ve 28. güne kadar devam eden süreçte PTH seviyesi anlamlı bir şekilde azalmaya başlamıştır $(p=0,0211)$. Bu azalan PTH seviyesi aynı şekilde akış hızı 1,2 mL/ 


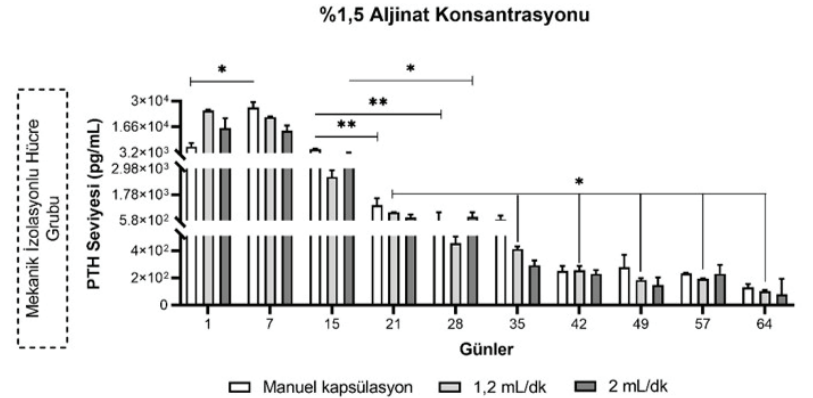

$\% 1,5$ Aljinat Konsantrasyonu



$\% 2$ Aljinat Konsantrasyonu

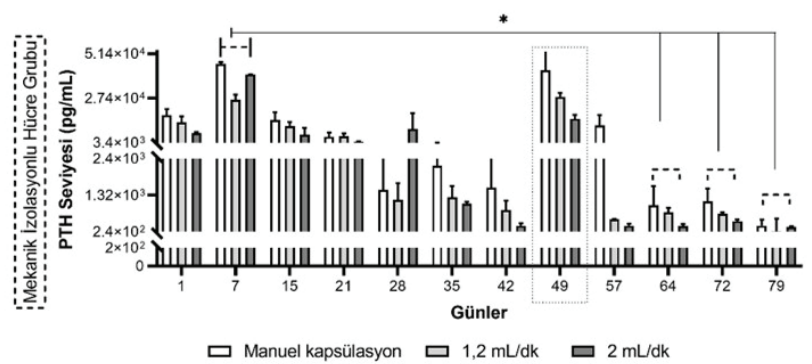

$\% 2$ Aljinat Konsantrasyonu

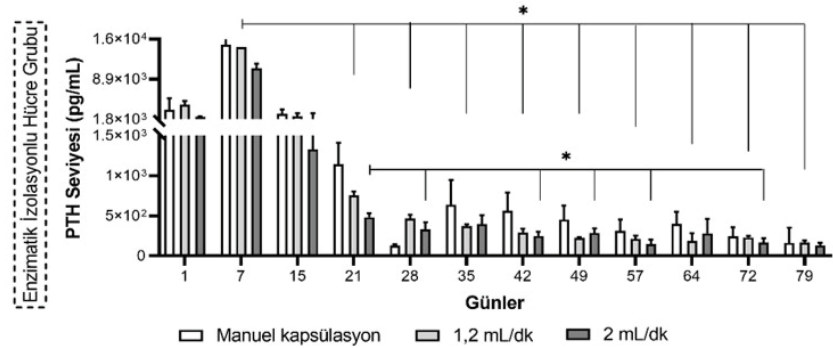

Şekil 2. El ile manuel olarak ve kapsülasyon cihazında iki farklı akış hızı (1,2 mL/dk ve $2 \mathrm{~mL} / \mathrm{dk}$ ) oluşturulan mikroenkapsüllerin ışık mikroskobu görüntüleri (büyütme oranı 4X). Farklı aljinat oranlarının kullanıldığı gruplarda hem mekanik hem de enzimatik izolasyon ile elde edilen hücreler kullanılmıştır. Üst panelde kapsülasyon işleminde \%1,2'lik aljinatın kullanıldığı gruplara ait kapsüller gösterilmektedir. El ile manuel olarak ve kapsülasyon cihazının 1,2 mL/dk akış hızında oluşturulan kapsüllerin boyutları arasında bir fark görülmemektedir. Cihaz akış hızı 2 mL/dk olarak uygulandığında kapsül boyutlarının küçüldüğü gözlemlenmektedir. Alt panelde kapsülasyon işleminde \%2'lik aljinatın kullanıldığı gruplara ait kapsüller gösterilmektedir. Bu grupta, \%1,2'lik aljinatın kullanıldığı grupta olduğu gibi benzer kapsül formasyonu gözlemlenmiş̧tir. \%2'lik aljinatın kullanıldığı enzimatik izolasyonlu hücrelerin kapsüle edildiği 2 akış hızına ait grupta kapsüller beklenenden küçük olduğu için 0,2 $2 \mu m$ çapındaki hücre strainer kullanılarak kültür takibi yapılmıştır.

dk olan grupta da 21. günden itibaren başlayarak aynı azalma örüntüsünü göstermiştir ( $p=0,0211-35$.gün; $p=0,0382-49$.gün; $p=0,0211-57$.gün; $p=0,0214-64$.gün). Bu değişim akış hızı 2 mL/ dk olan grubu için azalarak devam eden bir süreç gösterse de yalnızca 15. günden 28. güne kadar olan süre için PTH seviyesi azalmıştır ( $p=0,0201$ ) (Şekil 3).

İkinci grup olarak enzimatik izolasyonlu hücrelerin kullanıldığı kapsüllerden elde edilen PTH seviyesi; manuel olarak oluşturulan kapsüller için azalan bir parametre gösterse de 28. gün ve 42. gün aralığında artan PTH salınımı gözlenmiş ve istatistiksel olarak anlamlı bulunmuştur ( $p=0,0217)$. Süregelen takip boyunca, 42. gündeki artış 64. güne kadar yapılan zaman diliminde tekrar gözlenmemiştir.

Cihaz ile oluşturulan kapsüllerden akış hızı 1,2 mL/dk olan grupta 15 ve 28. günler aralığında anlamlı bir şekilde PTH seviyesinde azalma gözlenmiştir ( $p=0,0331)$. Buna bağlı olarak 64 güne kadar düşmeye devam etmiştir. Morfolojik olarak bu gruplarda kapsüllerde bir çatlama belirlenmemiştir. Akış hızının $2 \mathrm{~mL} / \mathrm{dk}$ olarak değerlendirildiği kapsüllerin 15. günden itibaren PTH salınımı anlamlı şekilde azalmaya devam ettiği fakat morfolojik olarak stabil bir yapı gösterdikleri belirlenmiştir $(p=0,0211-21$. gün; $p=0,0373-28$. gün; $p=0,0211-35$ ve 49. günler; $p=0,0347$ 57. gün; $p=0,0329-64$. gün) (Şekil 3).

\section{PTH Salınımına \%2 Aljinat Konsantrasyonunun Etkisi}

Salınan PTH miktarı açısından; \%2'lik aljinat konsantrasyonu hücre izolasyon tipine göre farklılıklar göstermiştir.

Mekanik izolasyonlu hücreler manuel olarak veya kapsülasyon cihazı kullanılmasından bağımsız bir şekilde kültürün 7. gününden sonra azalan bir eğri göstermiştir. Bu azalan parametre istatistiksel olarak; manuel yolla üretilen ve akış hızı $2 \mathrm{~mL} / \mathrm{dk}$ olan grupta kültürün 64., 72. ve 79. günlerinde anlamlılık gözlenmiştir (manuel olarak oluşturulan grup için $p=0,0272-64$. gün; $p=0,0225-$ 72. gün; $p=0,0211-79$. gün ve akış hızı $2 \mathrm{~mL} / \mathrm{dk}$ olan grupta ise $p=0,0211-64 ., 72$. ve 79. günler) (Şekil 3). İstisnai olarak 49. günde değerlendirilen üç metot için artan PTH seviyesi belirlenmiş fakat istatistiksel olarak anlamlı bulunmamıştır ( $p>0,05)$.

Enzimatik yöntemle izole edilen hücreler; manuel olarak kapsülasyon uygulandığında takip süresince azalan bir PTH salınımı göstermiş fakat istatistiksel olarak anlamlı bulunmamıştır ( $p>0,05)$. Kapsülasyon cihazının değerlendirildiği grupların ilki olan akış hızı 1,2 mL/dk olan grupta ise 7. günden 79. güne kadar olan süre de anlamlı şekilde PTH salınımı azalmıştır ( $p=0,0211 /$ tüm zamanlar). Akış hızı $2 \mathrm{ml} / \mathrm{dk}$ olan grupta ise 21. günden sonra azalan parametrede anlamlılık belirlenmiştir ( $p=0,0211-28$ ve 42. gün; $p=0,0215-49$. gün; $p=0,0211-57$ ve 72 . gün) (Şekil 3). 


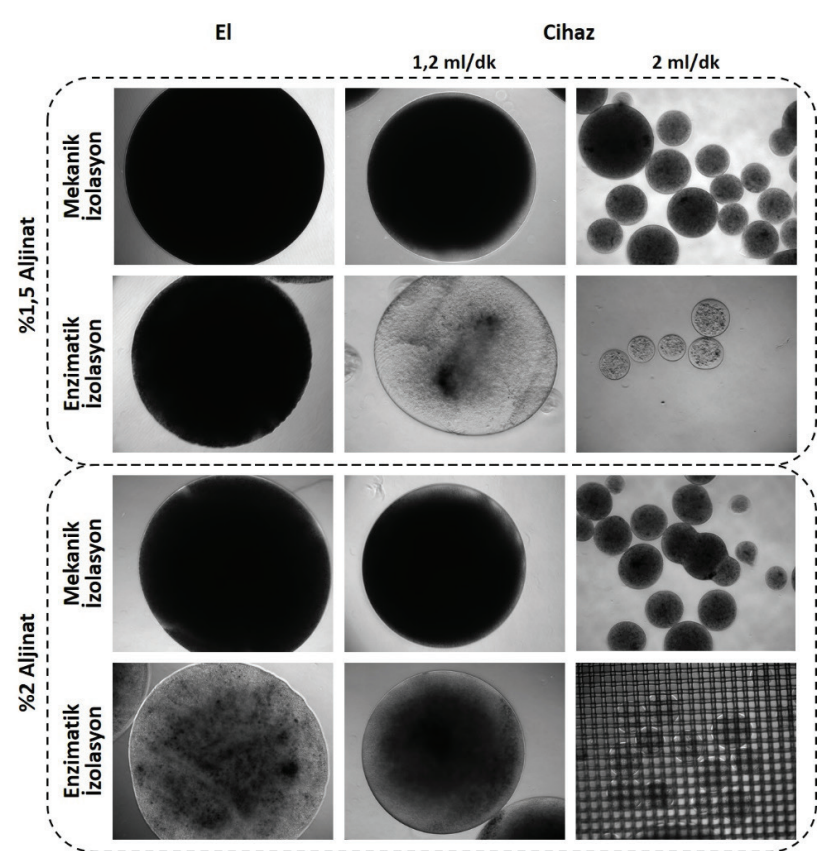

Şekil 3. İki farklı aljinat konsantrasyonu ve iki farklı izolasyon metodu ile elde edilen hücrelerin kullanıldığı mikroenkapsüllerin PTH salınım seviyelerinin takibi. Üst sol panelde \%1,5 aljinat kullanılarak mekanik izolasyona tabi tutulmuş hücrelerin kapsülasyonu gösterilmiştir. Alt sol panelde \%1,5 aljinat kullanılarak enzimatik izolasyona tabi tutulmuş hücrelerin kapsülasyonu gösterilmiştir. Üst sağ panelde \%2 aljinat kullanılarak mekanik izolasyona tabi tutulmuş hücrelerin kapsülasyonu gösterilmiştir. Alt sağ panelde \%2 aljinat kullanılarak enzimatik izolasyona tabi tutulmuş hücrelerin kapsülasyonu gösterilmiştir. PTH: Parathormon, pg/mL: pikogram/mililitre. ${ }^{*} p<0,05 .{ }^{* *} p<0,001$.

Kültür ortamındaki takip süresince, toplanan süpernatant örneklerindeki PTH miktarlarına ait detaylar Tablo 1'de gösterilmiştir.

\section{TARTIŞMA}

Aljinat, çok sayıda alg türünden izole edilebilir ve ana yapıları, dalsız ikili bloktan oluşan kopolimerler olarak tanımlanır. Bu blokları oluşturan yapılar; mannuronik ve guluronik asit bloklarıdır (3). Divalent katyonlar sayesinde farklı bağlanma sağlayan bu bloklar farklı por özelliklerine sahip küre şeklinde yapılar oluşturabilirler. Özellikle bu çalışma kapsamında kullanılan ultra saf aljinat \%60'tan fazla guluronik asit bloğu içeriğine sahiptir. Aljinatın bağ yapılarını oluşturma yetilerine göre divalent katyonlar sırasılyla $\mathrm{Pb}^{2+}>\mathrm{Cu}^{2+}>\mathrm{Cd}^{2+}>\mathrm{Ba}^{2+}>\mathrm{Sr}^{2+}>\mathrm{Ca}^{2+}>\mathrm{Co}^{2+}>-$ $\mathrm{Ni}^{2+}>\mathrm{Zn}^{2+}>\mathrm{Mn}^{2+}$ dır (17-19). Bu divalent katyonlar kullanıldıklarında ultra saf aljinatın yüksek guluronik asit içeriği sayesinde yumurta kutusu benzeri (egg-box like) por yapıları sağlayan küre formunu oluşturmaktadır $(3,17)$.

Bugüne kadar paratiroid dokusunun/hücrelerinin kapsülasyonu in vitro ve in vivo birçok çalışmada değerlendirilmiştir
$(2,10,15,20-25)$. Paratiroid hücrelerine spesifik çalışmalarıyla Hasse ve ark. baryum aljinat, mitojenik aljinat ve hem in vitro hem de in vivo için amitojenik aljinat dahil olmak üzere farklı aljinat türevlerini karşılaştırmıştır. Bu konudaki çalışmaların çoğunda ksenotransplantasyon uygulanmış ve 30 haftaya kadar takip ederek sonuçları literatüre katmıştır $(10,15,20,21,23,24)$.

Bunlardan ilki; Hasse ve ark. 1994 yılında immün sistemden kaçmak için mikroenkapsüle ettikleri paratiroid dokularını hipokalsemik sıçanlara naklettikleri çalışmadır. Sıçanların 90 günlük takibi boyunca normal değerlerde serum kalsiyum seviyesi gözlemlenmiştir. Bu bilgiler ışığında, mikroenkapsüle naklin immün yanıttan kaçarak uzun süreli sağkalımı sağladığı sonucuna ulaşılmıştır (20). Güncel olarak son yıllarda yapılan iki in vitro çalışma daha bulunmaktadır; Yucesan ve ark. 2017 yılında yayınladıkları bir çalışmada kapsülasyon için kullanılacak farklı paratiroid hücrelerinin sayısını değerlendirmişlerdir. 75 günlük in vitro takip sonucunda $20 \times 10^{6}$ paratiroid hücresinin aljinat ile kapsülasyonunun daha kararlı bir morfoloji gösterdiğini bildirmişlerdir (2).

Ayrıca, kapsüle edilmiş paratiroid dokusu/hücresi klinik uygulamalarda da kullanılmıştır. Kapsüle edilmiş paratiroid nakli, günümüze kadar on iki alıcı için uygulanmış ve yalnızca yedi vaka raporunda bildirilmiştir. İlk olarak, 1997 yılında Hasse ve ark. iki alıcı için ilk mikroenkapsüle paratiroid naklini gerçekleştirmiş ve üç aylık nakil sağkalımı bildirmiştir (22). İkinci nakil, Zimmerman ve ark.'nın 2001 yılında bir alıcı için gerçekleştirdikleri nakildir. Sağkalım açısından naklin üçüncü ayından sonra, alıcıda implantasyon alanından histolojik numune alınmış ve ne paratiroid doku partikülleri ne de mikrokapsüllere ait bir iz gözlemlemediklerini bildirilmiştir (26). Üçüncü çalışma, yine 2001 yılında Tibell ve ark.'nın uyguladıkları makrokapsül ile paratiroid doku partiküllerinin dört alıcıya naklidir ve bir yıla kadar nakil sağkalımı bildirilmiştir (27). Dördüncü nakil sunumunda, Ulrich ve ark. iki alıcının PTH seviyelerinde yükselmeler olduğunu ve daha sonra iki alıcının günlük ilaç gereksinimini yarı doza düşürdüğünü bildirmiştir (28). 2009'da Cabane ve ark. bir alıcıda enzimatik olarak izole edilmiş paratiroid hücrelerini mikroenkapsüle ederek nakil gerçekleştirdiler ve 20 aylık nakil sağkalımı ile en uzun takip verilerini bildirmiştir (29). Daha sonra Khryshchanovich ve ark. makroenkapsüllenmiş paratiroid doku parçalarını nakletmiş ve üç aylık takip verilerini literatüre sunmuştur (30). Mikroenkapsüle paratiroid hücre nakli ile ilgili son ve yedinci vaka bildirisi Yucesan ve ark. tarafından 2019 yılında bir alıcı için gerçekleştirilmiş ve nakil sonucunda bir yıl boyunca takip edilmiştir ve hasta günlük kullandığı ilaçların tamamını bıraktığı bildirilmiştir (11).

Bu çalışmada elde edilen verilere bakıldığında; manuel kapsülasyon açısından aljinat yüzdesi fark etmeksizin mekanik izolasyon grupları, takip süresinde 15. günden itibaren PTH salınımının anlamlı şekilde değiştiği belirlendi. Bunun en önemli nedenlerinden birisi olarak kapsül alanı içerisindeki hücrelerin ve/veya doku parçalarının yeterince besine erişim sağlayamamaları ihtimal dahilindedir. Ayrıca belirlenen günlerde azalan örüntüye rağmen yeniden bir PTH artışı gözlenmiştir. Bu artış morfolojik 


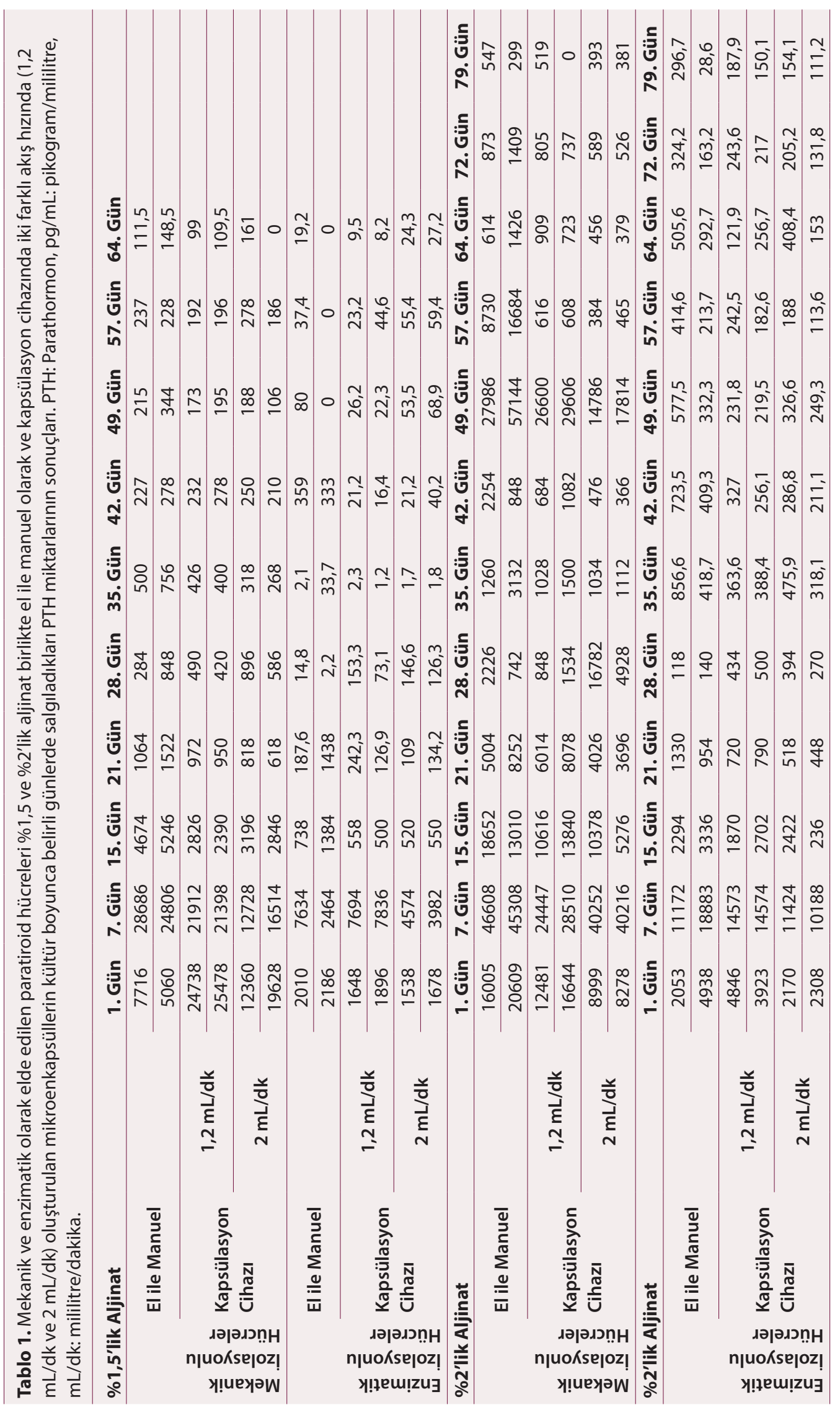


olarak kapsüllerin çatlamaya başladığı zaman diliminde belirlenmiştir ve bu artışın kapsül alanı içerisinde henüz salınmamış PTH'nın veya kapsül alanından ayrılan serbest hücrelerin açığa çıkmasından kaynaklandığı düşünülmektedir. Benzer bir bakış açısı ile enzimatik izolasyon değerlendirildiğinde aljinat yüzdesi anlam kazanmıştır. Düşük aljinat konsantrasyonunun kullanıldığı grupta (\%1,5 aljinat) azalan PTH salınımının, dalgalanan bir seyir gösterdiği ve özellikle manuel olarak üretilen kapsül gruplarında bu dalgalanma belirgin olarak görülmüştür. Morfolojik olarak yine bu grubun 28. günde ortaya çıkan yüzeysel çatlamalarının, dalgalanan seviyeyi etkilediği düşünülmektedir. Daha yüksek konsantrasyonda değerlendirilen aljinat grubunun (\%2) mekanik hücrelerin kapsüle edildiği ve cihaz sistemi kullanılan gruplarda da aynı morfolojik düzensizleşmeyle beraber, belirli bir noktada artış ve yeniden azalan bir PTH salınım sonucu vermiş̧tir. Bu ani artışın, yine kapsül yüzeyinde oluşan çatlama sebebiyle olduğu düşünülmektedir. Bilindiği üzere, mekanik izolasyonla elde edilen hücrelerin mikro-doku parçaları halinde bulundukları ve çatlama alanlarından ayrılan bu mikro-doku parçalarının süpernatant içerisindeki PTH miktarını doğrudan etkilemesi elde edilen verilerden de anlaşılmaktadır.

Kapsülasyon sistemi kullanılarak oluşturulan kapsül grubunda, aljinat yüzdesinden bağımsız olarak mekanik izolasyona tabii tutulan hücrelerin kapsüle edildiği grupta PTH salınım seviyeleri 15 ila 21. gün aralığından başlayarak değişmiştir. Enzimatik izolasyonlu hücrelerin kullanıldığı gruplarda, aljinat yüzdesi ve kapsülasyon sisteminin akış hızı morfolojik anlamda farklılık göstermiştir. \%1,5 ve \%2'lik aljinat grubunda 21-28 günlere ait zaman diliminde PTH salınımı her iki akış hızında azalma göstermiştir. Buna rağmen morfolojik stabilite yalnızca \%2'lik aljinat ile ve akış hızının $2 \mathrm{~mL} / \mathrm{dk}$ olduğu grupta korunmuştur. Ayrıca deneyin yapılan takip süreçlerine baktığımızda hücrelerin salgıladığı PTH miktarı \% 1,5 aljinat konsantasyonu için 64 güne kadar olup, \%2'lik aljinat konsantasyonu ise 79 güne kadar gerçekleştirilebilmiştir. Hücrelerin beslenebilme süreci \%2'lik aljinat konsantrasyonu için daha uzun devam edebilmiştir.

Çalışmanın bazı kısıtıııkları da mevcuttur. Özellikle kapsüle edilmemiş hücrelere ait in vitro takipler PTH seviyesi açısından değerlendirilememiştir. Bunun tek nedeni, yalnızca bir paratiroid dokusundan elde edilen hücrelerle, bütün grupların belirlenen limitlerde hem kapsül hem de çıplak hücre kültürü için sayıca yeterli gelmemesidir. Ayrıca kapsül içerisindeki hücrelerin canlılık tayinleri için floresan boyalarının uygulanarak canlılık açısından gözlenememesi bir başka kısıtlılıktır. Fakat çalışma süresince hem DAPI (moleküler ağırlığı 277,324 g/mol) hem de Hoechst 33342 (moleküler ağırlığı 452,6 g/mol) floresan boyaları kullanılarak kapsül alanı içerisindeki hücrelerin canlılıkları değerlendirilmek istenmiştir. Bu durum boyaların moleküler ağırlıklarının ultra saf aljinatın por alanlarından giremeyecek kadar büyük olabileceği ihtimalini düşündürmektedir. İlerleyen çalışmalar için daha düşük moleküler ağırlıklı floresan boyalar denenmesi planlanmaktadır.

Sonuç olarak; kapsülasyon sistemlerinin uzun vadede verimliliğinin arttırılması için yapının korunması ve gereken parametre- lerin optimize edilmesi sağlanmalıdır. Özellikle yüzey alanının arttırılması ve bunun uygun biyolojik olarak uyumlu polimer konsantrasyonu ile dengelenerek hücrelerin etkili beslenmesine olanak sağlanması gerekmektedir. Yapılan çalışma ile paratiroid dokusu hücreleri için uygun hücre izolasyon tipinin enzimatik hücre izolasyonu olduğu, \%2'lik aljinat konsantrasyonunun daha uzun hücre sağkalımını desteklediği ve kapsülasyon sisteminin $2 \mathrm{~mL} / \mathrm{dk}$ akış hızı ile daha stabil bir yapı oluşturduğu belirlenmiştir. İlerleyen çalışmalar ile daha çok sayıda paratiroid hücresi kullanılarak, belirlenen kriterlerin daha uzun süreli takiplerle değerlendirilmesi ve optimum koşulların tespit edilmesi hedeflenmektedir.

Teşekkür: Ekipman desteği için Bezmialem Vakıf Üniversitesi Tıbbi Biyoloji AD. 'dan Prof. Dr. Fahri Akbaş'a teşekkür ederiz.

Hakem Değerlendirmesi: Dış bağımsız.

Etik Komite Onayı: Bezmialem Vakıf Üniversitesi girişimsel olmayan araştırmalar etik kurulu onayı ile Helsinki Deklarasyonu prensiplerine uygun olarak gerçekleştirilmiştir (Kabul numarası: 54022451050.05.04-522). Çalışma kapsamında kullanılan paratiroid dokusu için hastadan imzalanmış gönüllü onam formu alınarak deneysel süreçler başlatılmıştır.

Yazar Katkıları: Çalışma Konsepti/Tasarımı - Ö.F.D., B.G.; Veri Toplama Ö.F.D., B.G.; Veri Analizi/Yorumlama - Ö.F.D., B.G., E.Y.; Yazma - Ö.F.D., B.G.; İçeriğin Eleştirel İncelemesi - B.G., E.Y., Y.E.E.; Son Onay ve Sorumluluk - E.Y., H.S.K., Y.E.E., A.A.

Çıkar Çatışması: Yazarlar çıkar çatışması bildirmemişlerdir.

Finansal Destek: Yazarlar bu çalışmada finansal destek almadıklarını beyan etmişlerdir.

Acknowledgment: We would like to thank for Equipment Facility to Prof Dr. Fahri Akbaş from Medical Biology of Bezmialem Vakif University.

Peer-review: Externally peer-reviewed.

Ethics Committee Approval: It was made in accordance with the approval of the Bezmialem Vakif University non-interventional research ethics committee and the principles of the Declaration of Helsinki (Acceptance Number: 54022451-050.05.04-522). For the parathyroid tissue used in the study, a signed voluntary consent form was obtained from the patient, and the experimental processes were started.

Author Contributions: Conception/Design of Study - Ö.F.D., B.G.; Data Collection - Ö.F.D., B.G.; Analysis and/or Interpretation - Ö.F.D., B.G., E.Y.; Drafting Manuscript - Ö.F.D., B.G.; Critical Revision of Manuscript - B.G., E.Y., Y.E.E.; Final Approval and Accountability - E.Y., H.S.K., Y.E.E., A.A.

Conflict of Interest: The authors have no conflict of interest to declare.

Financial Disclosure: The authors declared that this study has received no financial support 


\section{KAYNAKLAR/REFERENCES}

1. Candlin JP. Chapter 3 Polymeric Materials: Composition, Uses and Applications. In: Chalmers JM, Meier RJ, editors. Comprehensive Analytical Chemistry 53: Elsevier; 2008. p. 65-119. [CrossRef]

2. Yücesan $E$, Başoğlu H, Göncü B, Kandaş N, Ersoy $Y$, Akbaş, $F$, et al. In-vitro optimization of microencapsulated parathyroid cells. Dicle Medical Journal 2017; 44(4): 373-80. [CrossRef]

3. Goncu B, Yucesan E. Microencapsulation for Clinical Applications and Transplantation by Using Different Alginates. IntechOpen; 2021.4. [CrossRef]

4. Lu Q, Yang Z, Meng X, Yue Y, Ahmad MA, Zhang W, et al. A Review on Encapsulation Technology from Organic Light Emitting Diodes to Organic and Perovskite Solar Cells. Adv Funct Mater 2021; 31: 2100151. [CrossRef]

5. Güven ŞY. Biyouyumluluk Ve Biyomalzemelerin Seçimi. Suleyman Demirel University Journal of Engineering Sciences and Design 2014; 2(3): 303-11.

6. Carvalho DN, Inácio $A R$, Sousa RO, Reis RL, Silva TH. Chapter 18 - Seaweed polysaccharides as sustainable building blocks for biomaterials in tissue engineering. In: Torres MD, Kraan S, Dominguez $\mathrm{H}$, editors. Sustainable Seaweed Technologies: Elsevier; 2020. p. 543-87. [CrossRef]

7. Omami M, McGarrigle JJ, Reedy M, Isa D, Ghani S, Marchese E, et al. Islet Microencapsulation: Strategies and Clinical Status in Diabetes. Curr Diab Rep 2017; 17(7): 47. [CrossRef]

8. Woodhams L, Al-Salami H. The roles of bile acids and applications of microencapsulation technology in treating Type 1 diabetes mellitus. Ther Deliv 2017; 8(6): 401-9. [CrossRef]

9. Yücesan E, Göncü B, Başoğlu H, Özten Kandaş N, Kanımdan E, Akbaş F, Yeliz Ersoy E, Ayşan E. Experimental Alternative Method for the Treatment of Hypothyroidism: Capsulation of the Thyroid Tissue. Akdeniz Med J 2018; 5(3): 417-23. [CrossRef]

10. Hasse C, Zielke A, Klock G, Schlosser A, Barth P, Zimmermann $U$, et al. Amitogenic alginates: key to first clinical application of microencapsulation technology. World J Surg 1998; 22(7): 65965. [CrossRef]

11. Yucesan E, Basoglu H, Goncu B, Akbas F, Ersoy YE, Aysan E. Microencapsulated parathyroid allotransplantation in the omental tissue. Artif Organs 2019; 43(10): 1022-7. [CrossRef]

12. Aysan E, Kilic U, Gok O, Altug B, Ercan C, Kesgin Toka C, et al. Parathyroid Allotransplant for Persistent Hypocalcaemia: A New Technique Involving Short-Term Culture. Exp Clin Transplant 2016; 14(2): 238-41.

13. Aysan E, Altug B, Ercan C, Kesgin Toka C, Idiz UO, Muslumanoglu M. Parathyroid Allotransplant With a New Technique: A Prospective Clinical Trial. Exp Clin Transplant 2016; 14(4): 431-5.

14. Brown WH. I. Parathyroid Implantation in the Treatment of Tetania Parathyreopriva. Ann Surg 1911; 53(3): 305-17. [CrossRef]

15. Hasse C, Zielke A, Klock G, Barth P, Schlosser A, Zimmermann U, et al. First successful xenotransplantation of microencapsulated human parathyroid tissue in experimental hypoparathyroidism: long-term function without immunosuppression. J Microencapsul 1997; 14(5): 617-26. [CrossRef]

16. Yucesan E, Goncu B, Basoglu H, Ozten Kandas N, Ersoy YE, Akbas $\mathrm{F}$, et al. Fresh tissue parathyroid allotransplantation with shortterm immunosuppression: 1-year follow-up. Clin Transplant 2017; 31(11). [CrossRef]
17. de Vos P, Lazarjani HA, Poncelet D, Faas MM. Polymers in cell encapsulation from an enveloped cell perspective. Adv Drug Deliv Rev 2014; 67-68: 15-34. [CrossRef]

18. Poojari R, Srivastava R. Composite alginate microspheres as the next-generation egg-box carriers for biomacromolecules delivery. Expert Opin Drug Deliv 2013; 10(8): 1061-76. [CrossRef]

19. Lopes M, Abrahim B, Veiga F, Seiça R, Cabral LM, Arnaud P, et al. Preparation methods and applications behind alginate-based particles. Expert Opin Drug Deliv 2017; 14(6): 769-82. [CrossRef]

20. Hasse C, Schrezenmeir J, Stinner B, Schark C, Wagner PK, Neumann K, et al. Successful allotransplantation of microencapsulated parathyroids in rats. World J Surg 1994; 18(4): 630-4. [CrossRef]

21. Hasse C, Klock G, Zielke A, Schlosser A, Barth P, Zimmermann U, et al. Transplantation of parathyroid tissue in experimental hypoparathyroidism: in vitro and in vivo function of parathyroid tissue microencapsulated with a novel amitogenic alginate. Int J Artif Organs 1996; 19(12): 735-41. [CrossRef]

22. Hasse C, Klock G, Schlosser A, Zimmermann U, Rothmund M. Parathyroid allotransplantation without immunosuppression. Lancet 1997; 350(9087): 1296-7. [CrossRef]

23. Hasse C, Schlosser A, Klock G, Barth P, Stinner B, Zimmermann $\mathrm{U}$, et al. [Heterologous transplantation of human parathyroid glands after microencapsulation with clinically suitable alginate : long-term function without immunosuppression in the animal model]. Langenbecks Arch Chir Suppl Kongressbd 1998; 115(Suppl I): 713-8.

24. Hasse C, Bohrer T, Barth P, Stinner B, Cohen R, Cramer H, et al. Parathyroid xenotransplantation without immunosuppression in experimental hypoparathyroidism: long-term in vivo function following microencapsulation with a clinically suitable alginate. World J Surg 2000; 24(11): 1361-6. [CrossRef]

25. Hasse C, Brune M, Lorenz W, Barth P, Metzler W, Breves G, et al. Functional parameters before and after parathyroidectomy: a prospective, randomized long-term trial on different rat strains. Exp Clin Endocrinol Diabetes 2004; 112(7): 364-72. [CrossRef]

26. Zimmermann U, Cramer H, Jork A, Thürmer F, Zimmermann $H$, Fuhr G, et al. Microencapsulation-Based Cell Therapy. Biotechnology 2001: 547-71. [CrossRef]

27. Tibell A, Rafael E, Wennberg L, Nordenstrom J, Bergstrom M, Geller RL, et al. Survival of macroencapsulated allogeneic parathyroid tissue one year after transplantation in nonimmunosuppressed humans. Cell Transplant 2001; 10(7): 591-9. [CrossRef]

28. Ulrich F, Klupp J, Thürmer F, Rayes N, Seehofer D, Tullius S, et al. Allotransplantation of Encapsulated Human Parathyroid Tissue in Patients With Permanent Hypoparathyroidism. Transplantation 2004; 78: 79. [CrossRef]

29. Cabane P, Gac P, Amat J, Pineda P, Rossi R, Caviedes R, et al. Allotransplant of microencapsulated parathyroid tissue in severe postsurgical hypoparathyroidism: a case report. Transplant Proc 2009; 41(9): 3879-83. [CrossRef]

30. Khryshchanovich V, Ghoussein Y. Allotransplantation of macroencapsulated parathyroid cells as a treatment of severe postsurgical hypoparathyroidism: case report. Ann Saudi Med 2016; 36(2): 1437. [CrossRef] 